\title{
Effect of urea, bio-fertilizers and their interaction on the growth, yield and yield attributes of Cyamopsis Tetragonoloba
}

\author{
Asma Gul ${ }^{1}$, Abdul Salam*2, Muhammad Siddique Afridi ${ }^{2,3}$, Naila Khan Bangash ${ }^{2}$, Fawad Ali², \\ Muhammad Yuosaf Ali ${ }^{4}$, Shumaila Khan ${ }^{1}$ and Ramsha Mubeeen ${ }^{2}$
}

Department of Life Sciences,

Baghdad-ul-Jadeed Campus, The Islamia University of Bahawalpur, 63100, Pakistan.

Received: 23-10-2018

Accepted: 21-05-2019

DOI: 10.18805/IJARe.A-395

\begin{abstract}
A field experiment was conducted at Agriculture Research Station Bahawalpur (Pakistan) during Kharif, 2016 to evaluate the response of cluster bean against bio and chemical fertilizers. The treatments consisted of three levels of nitrogen (urea $75 \mathrm{~g}, 85 \mathrm{~g}$ and $95 \mathrm{~g} / 40 \mathrm{~g}$ seeds) with three level of Rhizobium $(1.5 \mathrm{~g}, 2.0 \mathrm{~g}$ and $2.5 \mathrm{~g} / 40 \mathrm{~g}$ of seeds). The experiment arranged in a randomized complete block design with 16 treatments and three replications. Combine treatment of urea and Rhizobium resulted in maximum plant height, number of pods/plants, number of seeds/pod, 1000 seeds weight, yield/plant, and chlorophyll content. Similarly, application of $2.5 \mathrm{~g}$ rhizobium and $85 \mathrm{~g}$ of urea separately resulted in highest number of leaves. Our results concluded that the use of urea and rhizobium in consortium could be a potential agronomic practice for the production of high grain yield in cluster bean.
\end{abstract}

Key words: Cluster bean, Growth, Rhizobium, Seed yield, Urea.

\section{INTRODUCTION}

Soil, a vital component for plant germination and survival must enrich from all macro and micro nutrients in sufficient and balanced quantities for their growth and nourishment. Chemical fertilizers provide essential plant nutrients, but it also toxic the soil which effect plant and animal health direct and indirectly. Bio fertilizer could address the problem of low soil fertility and improve agricultural productivity and food security. Physical or chemical properties of soils are less responsive to changing soil conditions than biological properties (Kowaljow and Mazzarino, 2007; Melero et al., 2007). Moreover, soil organic matter in a particular soil is greatly influenced by vegetation, climate change, soil reaction and biological conditions (Meena and Sharma, 2016). Microbe are able to grow under harsh conditions and gives some important understandings regarding their ability to increase under the ecological limitations of the environment (Muzamil Shah and Muhammad Zubair, 2018).

The efficient use of nutrients is one of the most important factors in any program designed to achieve an economic increase in agricultural production. Continuous and unbalanced use of nutrients is an important area of concern. Soil degradation and depletion of fertility due to the unbalanced and inadequate use of nutrients is largely responsible for the reduction of crop productivity.
Maintaining soil health through balanced nutrition is essential to maintain crop productivity (Meena et al., 2017). Soil fertility can also be regulated by soil microbial enzymatic activities which are responsible for the soil properties and cultivation factors (Corstanje et al., 2007). The depletion of the soil organic matter can be prevented by the biofertilizer particularly rhizobia, which is an alternative source of Nfertilizer (Jeyabal and Kuppuswamy, 2001).

The intimate symbiotic relationship between rhizobia and legumes result in nodule formation by lipochitooligosaccharide (LCO) signals and enhance yield (Lhuissier et al., 2001; Matiru and Dakora, 2004). In order to raise the soil fertility and crop production, bio-fertilizers have been recognized as a substitute to chemical fertilizers in sustainable farming (Manral and Saxena, 2003). Rhizosphere harbors diverse and rich regime of beneficial microorganisms which directly affect plant health and soil fertility in which a significant number of bacterial and fungal species have a mutual association with plants. They are able to bring useful effects in plant growth (Belay et al., 2001). In agricultural practices, use of beneficial microbes was started about 50 years ago. Now there is rising indication that these useful microbial populations can also improve plant opposition to contrary environmental stresses, e.g. heavy metal, impurity of water and nutrient deficiency (Chemining'wa and Vessey, 2006; Verma et al., 2011).

\footnotetext{
*Corresponding author's e-mail: Abdul_pk@yahoo.com

${ }^{1}$ Department of Life Sciences, Baghdad-ul-Jadeed Campus, The Islamia University of Bahawalpur, 63100, Pakistan.

${ }^{2}$ Department of Plant Sciences, Quaid-I-Azam University Islamabad, 45320, Pakistan.

${ }^{3}$ Biological Control of Plant Diseases, Department of Plant Pathology, Federal University of Lavras, University Campus, CP3037, Lavras, MG, Brazil.

${ }^{4}$ Department of Forestry, Range and Wildlife, Baghdad-ul-Jadeed Campus, The Islamia University of Bahawalpur, 63100, Pakistan.
} 
In oil yielding legumes, minerals and $\mathrm{N}$ fertilization are crucial factors which results high yield (Rathke et al., 2005). Deficiency of $\mathrm{N}$ is a major limiting factor for high yielding crops all over the world. It has been assessed that the microbial activities of Rhizobium fixed about $40-250 \mathrm{~kg}$ N/ha/year by diverse leguminous crops. Yield can be increased up to $10-35 \%$ by the bio-augmentation of Rhizobium (Namvar et al., 2011).

The cluster bean also known as Guar [Cyamopsis tetragonoloba (L.) Taub] is an annual legume that occupies a substantial part of moisture deficient areas of the subcontinent. The main uses include green fertilizers, grains and animal feed (Douglas, 2005). The ideal environment of its optimal germination is hot condition where soil has temperature more than $25^{\circ} \mathrm{C}$. Neutral conditions of soils ( $\mathrm{pH}$ 7) are favourable for the plants while guar grows effectively on soil ranging in $\mathrm{pH}$ from 5.3 to 8.3 (Jackson and Doughton, 1982). This legume is a very valued plant within a crop rotation cycle, as it survives in symbiosis with nitrogen-fixing bacteria. In pulses nitrogenous fertilizers application enhance yield (Corstanje et al., 2007). Guar inoculation with Rhizobium increased seed yield, number of nodules, nodules fresh weight, plant dry weight, nitrogen fixation and total nitrogen content (Singh and Singh, 1989). Hence this study was under taken with the objective of effect of chemical fertilizers and rhizobium inoculation on growth, inflorescence and yield attributes of guar [Cyamopsis tetragonoloba (L.) Taub].

\section{MATERIALS AND METHODS}

Description of experimental area: A field experiment was conducted at Agricultural Research Station (Bahawalpur, Pakistan) situated at $29^{\circ} 23^{\prime} 44^{\prime \prime} N 71^{\circ} 41^{\prime} 1^{\prime \prime} \mathrm{E}$ and elevated at $461 \mathrm{~m}$ above sea level (ASL). The crop was cultivated during Kharif, 2016. Before sowing, soil samples were taken and subjected to physical and chemical analysis at soil and water testing laboratory Bahawalpur following the method of Estefan et al. (2013). The soil texture of the experimental site was loamy. The maximum minimum, and relative humidity were collected on daily basis from the Pakistan Meteorological Department. Soil analysis and weather data are shown in Tables 1, 2 .

Experimental set up, plant material and treatments: The experiment was laid out in a randomized complete block design (RCBD) with three replications. The seeds of guar variety viz. 99BR used in the experiment were obtained from Guar Research Station Bahawalpur. Plants were treated with three different levels of a bio-fertilizer (Rhizobium at $1.5 \mathrm{~g} /$ $40 \mathrm{~g}$ seeds, $2.0 \mathrm{~g} / 40 \mathrm{~g}$ seeds and $2.5 \mathrm{~g} / 40 \mathrm{~g}$ seeds), three level of a nitrogen source (urea at $75 \mathrm{~g} / 40 \mathrm{~g}$ seed, $85 \mathrm{~g} / 40 \mathrm{~g}$ seed and $95 \mathrm{~g} / 40 \mathrm{~g}$ seeds) and one treatment without urea and Rhizobium was taken as contro1. Rhizobium japonicum used in this study was provided by Annex crop science company Multan, Pakistan. Seeds were treated at the time of sowing. Two percent guar gum was applied on overnight soaked seeds, mixed thoroughly in polythene bags with slurry of rhizobium, urea and their mixture and sown immediately in the field. The experimental unit area (plot) was $12.96 \mathrm{~m}^{2}$ consisting of 4 rows, $1.8 \mathrm{~m}$ width and $7.2 \mathrm{~m}$ length and were sown with hand drill method keeping row to row distance of $45 \mathrm{~cm}$. All the excess seedlings were thinned out 15 DAS by maintaining a spacing of $15 \mathrm{~cm}$ between two plants in a line. Crop was irrigated four times i.e. first irrigation after 35 days, $2^{\text {nd }}$ irrigation at flowering stage, $3^{\text {rd }}$ at pod appearance and $4^{\text {th }}$ at grain formation. The crop was harvested on $10^{\text {th }}$ of November 2016 when it retained $10 \%$ moisture level.

Data collection: Data was collected from tagged plants in order to record morphological, yield and inflorescence parameters. Plant height, number of leaves/plant, stem diameter ( $\mathrm{mm})$, number of pods/plants, number of pods/ cluster, number of cluster/plant, length of pod $(\mathrm{cm})$, Chlorophyll contents and size of ovary was measured via stereomicroscope at physiological maturity. Number of seeds/pod, weight of seeds/plant, 1000 seeds weight (g) and yield per plot was recorded from harvested plants. Yield per plot $\left(\mathrm{g} / \mathrm{m}^{2}\right)$ was converted to $\mathrm{kg} / \mathrm{ha}$.

Table 1: Soil Analysis Report.

\begin{tabular}{lcccccccc}
\hline $\begin{array}{l}\text { Depth } \\
(\mathbf{c m})\end{array}$ & $\begin{array}{c}\text { E.C } \\
\left(\mathbf{d S m} \mathbf{-}^{-1}\right)\end{array}$ & $\mathbf{p H}$ & $\begin{array}{c}\text { Organic } \\
\text { Matter }(\boldsymbol{\%})\end{array}$ & $\begin{array}{c}\text { Available } \\
\text { Phosphorus } \\
(\mathbf{p p m})\end{array}$ & $\begin{array}{c}\text { Available } \\
\text { Potassium } \\
(\mathbf{p p m})\end{array}$ & $\begin{array}{c}\text { Saturation } \\
\text { \%age }\end{array}$ & Texture & Remarks \\
\hline $15.3-30.5$ & 3 & 8.4 & 0.77 & 7.5 & 139 & 48 & Loam & Normal \\
\hline
\end{tabular}

Table 2: Weather data during experiment period.

\begin{tabular}{|c|c|c|c|c|c|c|c|c|}
\hline \multirow[t]{2}{*}{ Month } & \multicolumn{2}{|c|}{$\operatorname{Max} \operatorname{Temp}^{\circ} \mathrm{C}$} & \multicolumn{2}{|c|}{ Min Temp ${ }^{\circ} \mathrm{C}$} & \multicolumn{2}{|c|}{ Humidity (\%) } & \multirow{2}{*}{$\begin{array}{l}\text { Rain fall } \\
\text { (mm) }\end{array}$} & \multirow{2}{*}{$\begin{array}{c}\text { Cloudy } \\
\text { day }\end{array}$} \\
\hline & Avg & Range & Avg & Range & Avg & Range & & \\
\hline Jul & 43 & $40-46$ & 27 & $24-30$ & 77 & $73-80$ & 9 & 4 \\
\hline Aug & 40 & $38-42$ & 28 & $27-390$ & 75 & $68-80$ & 4 & 2 \\
\hline Sep & 35 & $31-39$ & 24 & $22-27$ & 74 & $62-85$ & 5 & 2 \\
\hline Oct & 33 & $29-36$ & 21 & $19-25$ & 74 & $68-80$ & _ & - \\
\hline Nov & 26 & $29-38$ & 22 & $22-26$ & 73 & $63-84$ & _ & - \\
\hline
\end{tabular}

Max Temp: Maximum Temperature, Min Temp: Minimum Temperature, Avg: Average. 
Statistical analysis: The collected data were subjected to analysis of variance, descriptive analysis and Duncan Multiple Range Test (DMRT) to find out the specific differences between the pairs of means (IBM Corp. Released 2012. IBM SPSS Statistics for Windows, Version 21.0. Armonk, NY: IBM Corp). Correlations of morphological, growth, yield and inflorescence characters were estimated by using Pearson correlations.

\section{RESULTS AND DISCUSSION}

Growth parameters: Among the treatment combination (Table 3), combined application of urea $95 \mathrm{~g}+R$. japonicum $2.0 \mathrm{~g}$ showed maximum plant height, while a lower dose (urea $75 \mathrm{~g}+R$. japonicum $1.5 \mathrm{~g}$ ) showed the highest stem diameter. Highest number of leaves recorded for alone $R$. japonicum $2.5 \mathrm{~g}$. It may be due to the enhanced $R$. japonicum inoculation and more availability of soluble nitrogen to the crop. It also reveals that $2.0 \mathrm{~g}$ to $2.5 \mathrm{~g} R$. japonicum has better effects on number of leaves per plant. The results indicated that morphological characters like plant height and stem diameter are significantly increased by combine treatments of $R$. japonicum and urea as compared to control and other treatments. Number of leaves also showed good results in combine treatments but significantly enhanced by the alone treatment of $R$. japonicum as compared to control and other treatments. Some parameters such as plant height and stem diameter show both the maximum and minimum results in different doses of combined treatment of bio and chemical fertilizers. It might be due to the environmental effect or ineffective $R$. japonicum inoculation. Said-Al Ahl, (2005) reported that plant height, number of branches, plant fresh and dry weights, umbels number and fruits yield increased with nitrogen and bio-fertilizer treatment in Anethum graveolens, with the high dose of nitrogen producing the highest values. Nushair et al., (2018) also reported in Pigeon pea, Sweet pea and Chick pea that bio fertilizer application significantly increased plant height pod and seed weight. Hassan et al., (2012) stated that biofertilizer treatments enhanced plant height, branch number/ plant and plant dry weight. Growth parameters of guar can be much improved with application of nutrients in balanced ratio (Deshmukh et al., 2014). Nitrogen boosts new cells formation, promotes plant vigor and root growth, hastens leaf development which helps in harvesting more solar energy and extended utilization of nitrogen which can be attributed for higher plant height and branches/plant.

Chlorophyll contents: It is clear from the data (Table 3) that chlorophyll contents significantly enhanced by the combine application of urea and rhizobium (urea $75 \mathrm{~g}+R$. japonicum $2.5 \mathrm{~g}$ ). Highest chlorophyll contents recorded for treatment 10 and 11 (urea $75,85 \mathrm{~g}+1.5,2.5 \mathrm{~g}$ ). The results indicated that combined fertilizers (urea $+R$. japonicum) had positive effect on chlorophyll contents as compared to control and other treatments. Significant increase in chlorophyll content is an indication of higher $\mathrm{N}_{2}$ fixation due to $R$. japonicum application. Afridi et al., (2019) stated that the application of K.rhizophila and C. sakazakii enhanced chlorophyll contents up to $17 \%$ in screening wheat genotypes against salt stress. Nitrogen can increase photosynthesis process in plants. Alam and Haider, (2006) stated that increasing photosynthetic rate with $\mathrm{N}$ fertilization could be attributed to increasing amount of chlorophyll pigment, since $\mathrm{N}$ was one of the main components of chlorophyll. Shu et al., (2012) reported that nitrogenous compounds play a major role in protein and chlorophyll synthesis and thus increase the photosynthetic ability and consequently dry matter production.

Table 3: Effects of rhizobium inoculation and Urea fertilizers on Morphology and chlorophyll contents of cluster bean.

\begin{tabular}{llllllll}
\hline Treatments & $\begin{array}{l}\text { PH } \\
(\mathbf{c m})\end{array}$ & $\begin{array}{l}\text { Pod L } \\
(\mathbf{c m})\end{array}$ & $\begin{array}{l}\text { SD } \\
(\mathbf{m m})\end{array}$ & $\begin{array}{c}\text { OS } \\
(\boldsymbol{\mu m})\end{array}$ & $\begin{array}{l}\text { Chl a } \\
(\mathbf{m g} / \mathbf{g} \mathbf{F w})\end{array}$ & $\begin{array}{l}\text { Chl b } \\
(\mathbf{m g} / \mathbf{g} \mathbf{F w})\end{array}$ & $\begin{array}{l}\text { Total Chl } \\
(\mathbf{m g} / \mathbf{g F w})\end{array}$ \\
\hline T1: Seed (Control) & $84.1 \mathrm{ih}$ & $5.7 \mathrm{a}$ & $33.3 \mathrm{bc}$ & $28.7 \mathrm{~b}$ & $0.83 \mathrm{f}$ & $0.33 \mathrm{e}$ & $1.16 \mathrm{bcde}$ \\
T2: Seed + Urea 75 g & $86.7 \mathrm{k}$ & $5.7 \mathrm{a}$ & $35.9 \mathrm{e}$ & $36.7 \mathrm{f}$ & $0.59 \mathrm{~b}$ & $0.23 \mathrm{~b}$ & $0.82 \mathrm{bcde}$ \\
T3: Seed + Urea 85 g & $85.9 \mathrm{jk}$ & $5.8 \mathrm{a}$ & $36.1 \mathrm{ef}$ & $26.6 \mathrm{a}$ & $0.63 \mathrm{bc}$ & $0.24 \mathrm{bc}$ & $0.88 \mathrm{ab}$ \\
T4: Seed + Urea 95 g & $84.5 \mathrm{ij}$ & $5.7 \mathrm{a}$ & $37.1 \mathrm{fg}$ & $41.1 \mathrm{j}$ & $0.66 \mathrm{~cd}$ & $0.24 \mathrm{bc}$ & $0.91 \mathrm{abc}$ \\
T5: Seed + Rhizobium 1.5 g & $82.9 \mathrm{ghi}$ & $5.8 \mathrm{a}$ & $36.1 \mathrm{ef}$ & $30.3 \mathrm{c}$ & $0.54 \mathrm{a}$ & $0.18 \mathrm{a}$ & $0.73 \mathrm{a}$ \\
T6: Seed + Rhizobium 2 g & $78.2 \mathrm{~cd}$ & $5.7 \mathrm{a}$ & $34.6 \mathrm{de}$ & $40.4 \mathrm{i}$ & $0.82 \mathrm{f}$ & $0.25 \mathrm{bc}$ & $1.07 \mathrm{bcd}$ \\
T7: Seed + Rhizobium 2.5 g & $82.6 \mathrm{gh}$ & $5.8 \mathrm{a}$ & $37.3 \mathrm{fg}$ & $40.8 \mathrm{j}$ & $0.9 \mathrm{~g}$ & $0.25 \mathrm{bc}$ & $1.15 \mathrm{bcde}$ \\
T8: Seed + Urea 75 g + Rhizobium 1.5 g & $81.7 \mathrm{fg}$ & $5.8 \mathrm{a}$ & $40.8 \mathrm{~h}$ & $45.0 \mathrm{k}$ & $0.68 \mathrm{~d}$ & $0.22 \mathrm{ab}$ & $0.9 \mathrm{abc}$ \\
T9: Seed + Urea 75 g + Rhizobium 2 g & $72.1 \mathrm{a}$ & $5.9 \mathrm{a}$ & $30.1 \mathrm{a}$ & $39.1 \mathrm{~h}$ & $0.9 \mathrm{~g}$ & $0.28 \mathrm{~cd}$ & $1.19 \mathrm{cde}$ \\
T10: Seed + Urea 75 g + Rhizobium 2.5 g & $75.9 \mathrm{~b}$ & $5.7 \mathrm{a}$ & $34.7 \mathrm{de}$ & $39.2 \mathrm{~h}$ & $1.34 \mathrm{j}$ & $0.44 \mathrm{~g}$ & $1.78 \mathrm{~g}$ \\
T11: Seed + Urea 85 g + Rhizobium 1.5 g & $76.8 \mathrm{bc}$ & $5.8 \mathrm{a}$ & $32.4 \mathrm{~b}$ & $35.5 \mathrm{e}$ & $1.34 \mathrm{j}$ & $0.41 \mathrm{fg}$ & $1.76 \mathrm{~g}$ \\
T12: Seed + Urea 85 g + Rhizobium 2 g & $78.6 \mathrm{de}$ & $5.9 \mathrm{a}$ & $34.0 \mathrm{~cd}$ & $38.2 \mathrm{~g}$ & $1.19 \mathrm{i}$ & $0.39 \mathrm{f}$ & $1.59 \mathrm{fg}$ \\
T13: Seed + Urea 85 g + Rhizobium 2.5 g & $70.3 \mathrm{a}$ & $5.8 \mathrm{a}$ & $34.1 \mathrm{~cd}$ & $34.4 \mathrm{~d}$ & $0.75 \mathrm{e}$ & $0.23 \mathrm{~b}$ & $0.98 \mathrm{abc}$ \\
T14: Seed + Urea 95 g + Rhizobium 1.5 g & $80.2 \mathrm{ef}$ & $5.8 \mathrm{a}$ & $36.1 \mathrm{ef}$ & $36.8 \mathrm{f}$ & $1.06 \mathrm{c}$ & $0.31 \mathrm{de}$ & $1.37 \mathrm{ef}$ \\
T15: Seed + Urea 95 g + Rhizobium 2 g & 122.61 & $5.8 \mathrm{a}$ & $37.6 \mathrm{~g}$ & $39.5 \mathrm{~h}$ & $0.73 \mathrm{e}$ & $0.23 \mathrm{~b}$ & $0.96 \mathrm{abc}$ \\
T16: Seed + Urea 95 g + Rhizobium 2.5 g & $87.6 \mathrm{k}$ & $5.9 \mathrm{a}$ & $37.4 \mathrm{fg}$ & $35.8 \mathrm{e}$ & $0.91 \mathrm{~g}$ & $0.33 \mathrm{e}$ & $1.24 \mathrm{de}$ \\
\hline
\end{tabular}

Note: The different superscript letters indicate statistically significant differences by a Duncan's multiple range test at $\mathrm{P}=0.05$; $\mathrm{PH}$ : Plant Height, Po L: Pod Length, SD: Stem Diameter, OS: Size of Ovary, Chl: Chlorophyll. 
Table 4: Effects of rhizobium inoculation and Urea fertilizers on seed yield and yield contributing parameters of cluster bean.

\begin{tabular}{|c|c|c|c|c|c|c|c|c|}
\hline Treatment & $\begin{array}{l}\text { No Of } \\
\text { Pod/P }\end{array}$ & $\begin{array}{l}\text { No of } \\
\text { Pod/C }\end{array}$ & $\begin{array}{l}\text { No of } \\
\text { C/P }\end{array}$ & $\begin{array}{l}\text { No of } \\
\text { S/Po }\end{array}$ & $\begin{array}{l}\text { No of } \\
L / P\end{array}$ & $\begin{array}{l}\text { Yield/P } \\
\text { (gm) }\end{array}$ & $\begin{array}{l}1000 \\
\text { SW (gm) }\end{array}$ & $\begin{array}{l}\text { Yield } \\
\text { (kg/ha) }\end{array}$ \\
\hline T1: Seed (Control) & $190.9 \mathrm{a}$ & $18.1 \mathrm{a}$ & $13.6 \mathrm{a}$ & $8.5 \mathrm{a}$ & $13.8 \mathrm{a}$ & $21.8 \mathrm{ab}$ & $27.4 \mathrm{c}$ & $669.5 \mathrm{ab}$ \\
\hline T2: Seed + Urea $75 \mathrm{~g}$ & 193.9 a & $18.4 \mathrm{a}$ & $15.2 \mathrm{a}$ & $8.5 \mathrm{a}$ & $14.5 \mathrm{abc}$ & $25.7 \mathrm{ab}$ & $28.1 \mathrm{~d}$ & $787.9 \mathrm{ab}$ \\
\hline T3: Seed + Urea $85 \mathrm{~g}$ & $162.4 \mathrm{a}$ & $13.5 \mathrm{a}$ & $14.3 \mathrm{a}$ & $8.5 \mathrm{a}$ & $14.1 \mathrm{abc}$ & $17.5 \mathrm{a}$ & $29.3 \mathrm{gh}$ & $537.5 \mathrm{a}$ \\
\hline T4: Seed + Urea $95 \mathrm{~g}$ & $185.6 \mathrm{a}$ & $17.0 \mathrm{a}$ & $13.1 \mathrm{a}$ & $8.6 \mathrm{a}$ & $13.6 \mathrm{a}$ & $23.6 \mathrm{ab}$ & $29.6 \mathrm{~h}$ & $725.9 \mathrm{ab}$ \\
\hline T5: Seed + Rhizobium $1.5 \mathrm{~g}$ & $173.7 \mathrm{a}$ & $15.4 \mathrm{a}$ & $15.5 \mathrm{a}$ & $8.8 \mathrm{a}$ & $15.3 \mathrm{abcd}$ & $24.1 \mathrm{~b}$ & $30.8 \mathrm{ij}$ & $736.6 \mathrm{ab}$ \\
\hline T6: Seed + Rhizobium 2 g & $154.3 \mathrm{a}$ & $17.2 \mathrm{a}$ & $13.2 \mathrm{a}$ & $8.7 \mathrm{a}$ & $15.4 \mathrm{abcd}$ & $23.9 \mathrm{ab}$ & $22.6 \mathrm{a}$ & $734.3 \mathrm{ab}$ \\
\hline T7: Seed + Rhizobium 2.5 g & $215.7 \mathrm{a}$ & $18.2 \mathrm{a}$ & $16.8 \mathrm{a}$ & $8.6 \mathrm{a}$ & $16.7 \mathrm{~d}$ & $31.8 \mathrm{ab}$ & $27.9 \mathrm{~d}$ & $918.5 \mathrm{ab}$ \\
\hline T8: Seed + Urea $75 \mathrm{~g}+$ Rhizobium $1.5 \mathrm{~g}$ & $185.8 \mathrm{a}$ & $14.3 \mathrm{a}$ & $19.7 \mathrm{a}$ & $9.1 \mathrm{a}$ & $15.7 \mathrm{bcd}$ & $20.5 \mathrm{ab}$ & $26.2 \mathrm{~b}$ & $630.2 \mathrm{ab}$ \\
\hline T9: Seed + Urea 75 g + Rhizobium 2 g & $180.2 \mathrm{a}$ & $17.5 \mathrm{a}$ & $15.4 \mathrm{a}$ & $8.5 \mathrm{a}$ & $15.1 \mathrm{abcd}$ & $25.7 \mathrm{ab}$ & $28.1 \mathrm{~d}$ & $790.2 \mathrm{ab}$ \\
\hline T10: Seed + Urea $75 \mathrm{~g}+$ Rhizobium $2.5 \mathrm{~g}$ & $181.8 \mathrm{a}$ & $15.1 \mathrm{a}$ & $17.1 \mathrm{a}$ & $8.9 \mathrm{a}$ & $14.4 \mathrm{abc}$ & $22.3 \mathrm{ab}$ & $30.2 \mathrm{i}$ & $684.9 \mathrm{ab}$ \\
\hline T11: Seed + Urea $85 \mathrm{~g}+$ Rhizobium $1.5 \mathrm{~g}$ & $173.7 \mathrm{a}$ & $19.4 \mathrm{a}$ & $14.4 \mathrm{a}$ & $8.7 \mathrm{a}$ & $14.9 \mathrm{abc}$ & $21.9 \mathrm{ab}$ & 22.61 & $671.9 \mathrm{ab}$ \\
\hline T12: Seed + Urea $85 \mathrm{~g}+$ Rhizobium $2 \mathrm{~g}$ & $198.6 \mathrm{a}$ & $16.8 \mathrm{a}$ & $16.6 \mathrm{a}$ & $8.6 \mathrm{a}$ & $15.0 \mathrm{abc}$ & $25.4 \mathrm{ab}$ & $30.4 \mathrm{i}$ & $780.3 \mathrm{ab}$ \\
\hline T13: Seed + Urea $85 \mathrm{~g}+$ Rhizobium $2.5 \mathrm{~g}$ & $162.5 \mathrm{a}$ & $16.8 \mathrm{a}$ & $16.1 \mathrm{a}$ & $8.5 \mathrm{a}$ & $15.8 \mathrm{~cd}$ & $21.4 \mathrm{ab}$ & $29.0 \mathrm{fg}$ & $656.2 \mathrm{ab}$ \\
\hline T14: Seed + Urea $95 \mathrm{~g}+$ Rhizobium $1.5 \mathrm{~g}$ & $181.6 \mathrm{a}$ & $17.6 \mathrm{a}$ & $14.2 \mathrm{a}$ & $8.6 \mathrm{a}$ & $14.1 \mathrm{ab}$ & $22.1 \mathrm{ab}$ & $31.2 \mathrm{j}$ & $678.2 \mathrm{ab}$ \\
\hline T15: Seed + Urea 95 g + Rhizobium 2 g & $161.3 \mathrm{a}$ & $15.7 \mathrm{a}$ & $18.2 \mathrm{a}$ & $8.6 \mathrm{a}$ & $14.6 \mathrm{abc}$ & $19.7 \mathrm{ab}$ & $28.4 \mathrm{de}$ & $603.7 \mathrm{ab}$ \\
\hline T16: Seed + Urea $95 \mathrm{~g}+$ Rhizobium $2.5 \mathrm{~g}$ & $221.2 \mathrm{a}$ & $16.1 \mathrm{a}$ & $19.9 \mathrm{a}$ & $8.7 \mathrm{a}$ & $15.0 \mathrm{abcd}$ & $29.9 \mathrm{~b}$ & 28.7 ef & $977.6 \mathrm{~b}$ \\
\hline
\end{tabular}

Note: The different superscript letters indicate statistically significant differences by a Duncan's multiple range test at $\mathrm{P}=0.05 ; \mathrm{Po} / \mathrm{P}$ : Pods per Plant, Po/C: Pods per Cluster, L/P: Leaves per Plant, C/P: Clusters per Plant, S/Po: Seeds per Pod, Wt: Weight, S/P: Seeds per Plant, 1000 SW: 1000 Seed Weight, kg/ha: kilogram per hectare.

Yield and yield contributing attributes: Data presenting in Table 4 demonstrate the impact of sixteen treatments of bio ( $R$. japonicum) and chemical (urea) fertilizers on yield parameters. As regards number of pods per plant and number of pods per cluster, application of Urea $95 \mathrm{~g}+R$. japonicum $2.5 \mathrm{~g}$ and Urea $85 \mathrm{~g}+R$. japonicum $1.5 \mathrm{~g}$ recorded the highest values for both the parameters respectively. It indicates that combine application have positive effect on number of pods per plant. These results were supported by the findings of Prasanna et al., (2014). Our results were also confirmed by the finding of Tahir et al., (2009) who reported that application of $\mathrm{N}$ along with $\mathrm{P}$ and BradyR. japonicum resulted up to $94 \%$ increase in pod number per plant. The highest number of cluster per plant and seeds weight per plant recorded for Urea $95 \mathrm{~g}+R$. japonicum $2.5 \mathrm{~g}$. Application of Urea $85 \mathrm{~g}+R$. japonicum $2.0 \mathrm{~g}$ recorded highest pod length while application of Urea $75 \mathrm{~g}+R$. japonicum $1.5 \mathrm{~g}$ showed highest number of seeds per plant. These results were in confirmatory to the study of Rajput and Singh, (1996). Thousand seed weight was ranged from 22.64 to $31.21 \mathrm{~g}$ being highest for treatment T14 (Urea $95 \mathrm{~g}$ $+R$. japonicum $1.5 \mathrm{~g}$ ) whereas minimum for T6 $(R$. japonicum $2.0 \mathrm{~g}$ ). The maximum grain yield, 1000 seed weight, biological yield and harvest index was obtained in barley by treatment of highest level of nitrogen fertilizers, in contrast, to control which was similar to the findings of Mirshekari et al., (2012). Application of urea $95 \mathrm{~g}+$ rhizobium $2.5 \mathrm{~g}$ showed highest yield $(977.6 \mathrm{~kg} / \mathrm{ha})$ while minimum yield exhibited by application of alone urea $85 \mathrm{~g} /$ $40 \mathrm{~g}$ seeds. Our results were supported by the findings of Hossain et al., (2011). These results were also in confirmation with the results of Jatav et al., (2016) and Singh et al., (2014). Ibrahim et al., (2011) stated that yield parameters were significantly increased by the inoculation of BradyR. japonicum strain in guar cultivars. The results indicate that various combine treatments of biotic fertilizers $(R$. japonicum) and chemical fertilizer (urea) have positive effect on yield parameters as compare to control and other treatments. Saritha et al., (2013) conducted a study on the effect of certain organic manures on the seed germination and seedling growth of Cluster bean. It was found that best seedling and yield of the crop in cluster bean is possible by the treatment with panchagavya (or) bio fertilizer $(R$. japonicum).

\section{CONCLUSION}

The results in this study clearly indicated that chemical fertilizer with rhizobium inoculation significantly enhanced growth, yield components, and seed yield of cluster bean. The application of urea $95 \mathrm{~g}$ and $75 \mathrm{~g}$ with the inoculation of $1.5 \mathrm{~g}$ and $2.5 \mathrm{~g} R$. japonicum respectively recorded higher growth (plant height, branches/ plant, and dry matter); yield attributes (pods/plant, seeds/pod and 1000seed weight) and grain yield/ha as compared to control and other treatments. Whereas application of rhizobium $2.5 \mathrm{~g}$ alone is found to be more effective for some growth characters (leaf number) of cluster bean. So, it was concluded that the co-inoculation of rhizobia and urea fertilizers with appropriate doses may be recommended for obtaining the higher yield of cluster bean in the region.

\section{ACKNOWLEDGMENT}

Authors feel privileged to thank the Agriculture Research Station, Bahawalpur for providing the technical help and necessary material to carry out this work.

\section{CONFLICT OF INTEREST}

The authors declare that we have no conflict of interest. 


\section{REFERENCES}

Afridi M.S., Mahmood T., Salam A., Mukhtar T., Mahmood S., Ali J., Khatoon Z., Bibi M., Javed M.T., Sultan T. (2019). Induction of tolerance to salinity in wheat genotypes by plant growth promoting endophytes: Involvement of ACC deaminase and antioxidant enzymes. Plant Physiology and Biochemistry. https://doi.org/10.1016/j.plaphy.2019.03.041.

Alam M., Haider S. (2006). Growth attributes of barley (Hordeum vulgare L.) cultivars in relation to different doses of nitrogen fertilizer. J. Life Earth Sci. 1: 77-82.

Belay A., Claassens A., Wehner F., De Beer J. (2001). Influence of residual manure on selected nutrient elements and microbial composition of soil under long-term crop rotation. South African Journal of Plant and Soil. 18: 1-6.

Chemining'wa G.N., Vessey J.K. (2006). The abundance and efficacy of Rhizobium leguminosarum bv. viciae in cultivated soils of the eastern Canadian prairie. Soil Biology and Biochemistry. 38: 294-302.

Corstanje R., Reddy K., Prenger J., Newman S., Ogram A. (2007). Soil microbial eco-physiological response to nutrient enrichment in a sub-tropical wetland. Ecological indicators. 7: 277-289.

Deshmukh R., Nagre P., Wagh A., Dod V. (2014). Effect of different bio-fertilizers on growth, yield and quality of cluster bean. Indian Journal of Advances in Plant Research. 1: 39-42.

Douglas C. (2005) Evaluation of guar cultivars in central and southern queensland RIRDC.

Estefan, G., R. Sommer and J. Ryan. (2013). Methods of soil,plant and water analysis: A manual for the West Asia and North Africa Region. $3^{\text {rd }}$ ed. ICARDA, Beirut, Lebanon.

Hassan E., Ibrahim M., Khalifa Y. (2012). Efficiency of biofertilization on growth, yield, alkaloids content and chemical constitutes of Lupinus Termis, L. plants. Australian Journal of Basic and Applied Sciences. 6: 433-442.

Hossain M., Karim M., Biswas P., Kawochar M., Islam M. (2011). Effect of Rhizobium inoculation and chemical fertilization on the yield and yield components of mungbean. J. Expt. Biosci. 2: 69-74.

Ibrahim, K. A., Suliman, K. H., Abdalla, A. A., Zaied, M. M., Mohamed, E. A., Ahmed, A. I., \& Mukhtar, S. K. (2011). Response of growth, yield and seed quality of guar (Cyamopsis teteragonolopa L.) to Bradyrhizobium inoculations. Pakistan Journal of Nutrition, 10(9): 805-813.

Jackson K., Doughton J. (1982). Guar: a potential industrial crop for the dry tropics of Australia. Journal-Australian Institute of Agricultural Science.

Jatav M., Sharma B., Samadia D., Meena S. (2016). Efficacy of Rhizobium inoculation on graded N levels and net return from cluster bean seed production under hot arid regions. Economic Affairs. 61: 495.

Jeyabal A., Kuppuswamy G. (2001). Recycling of organic wastes for the production of vermicompost and its response in rice-legume cropping system and soil fertility. European Journal of Agronomy. 15: 153-170.

Kowaljow E., Mazzarino M.J. (2007). Soil restoration in semiarid Patagonia: Chemical and biological response to different compost quality. Soil Biology and Biochemistry. 39: 1580-1588.

Lhuissier F., De Ruijter N., Sieberer B., Esseling J., Emons A. (2001). Time course of cell biological events evoked in legume root hairs by Rhizobium Nod factors: state of the art. Annals of Botany. 87: 289-302.

Manral H., Saxena S. (2003). Plant growth, yield attributes and grain yield of soyabean as affected by the application of inorganic and organic sources of nutrients. Bioresour. Technol. 92: 110-118.

Matiru V.N., Dakora F.D. (2004). Potential use of rhizobial bacteria as promoters of plant growth for increased yield in landraces of African cereal crops. African Journal of Biotechnology. 3: 1-7.

Meena H.M., Sharma R. (2016). Long-Term effect of fertilizers and amendments on different fractions of organic matter in an acid Alfisol. Communications in Soil Science and Plant Analysis. 47: 1430-1440.

Meena H.M., Sharma R., Sankhyan N., Sepehya S. (2017). Effect of continuous application of fertilizers, farmyard manure and lime on soil fertility and productivity of the maize-wheat system in an Acid Alfisol. Communications in Soil Science and Plant Analysis. 48: 1552-1563.

Melero S., Madejón E., Ruiz J.C., Herencia J.F. (2007). Chemical and biochemical properties of a clay soil under dryland agriculture system as affected by organic fertilization. European Journal of Agronomy. 26: 327-334.

Mirshekari B., Hokmalipour S., Sharifi R.S., Farahvash F., Gadim A. (2012). Effect of seed biopriming with plant growth promoting rhizobacteria (PGPR) on yield and dry matter accumulation of spring barley (Hordeum vulgare L.) at various levels of nitrogen and phosphorus fertilizers. J Food Agric Environ. 10: 314-20.

Muzamil Shah, Fariha Hasan, Syed Salman Hashmi, Wali Muhammad, Muhammad Zubair, Muhammad Asad Ullah. (2018). Diversity of halophiles in Karak salt mine, KP, Pakistan and their ability to produce enzyme of industrial importance. Int. J. Biosci. 13(1): 257-266. .DOI: dx.doi.org/10.12692/ijb/13.1.257-266.

Namvar A., Sharifi R.S., Sedghi M., Zakaria R.A., Khandan T., Eskandarpour B. (2011). Study on the effects of organic and inorganic nitrogen fertilizer on yield, yield components, and nodulation state of Chickpea (Cicer arietinum L.). Communications in Soil science and Plant Analysis. 42: 1097-1109.

Nushair A.M., Saha A.K., Mandal A., Rahman M., Mohanta M.K., Hasan M., Haque M.F. (2018). Rhizobium sp. CCNWYC119: a single strain highly effective as biofertilizer for three different peas (Pigeon pea, Sweet pea and Chick pea). Legume Research: An International Journal. 41.

Prasanna K.L., Selvaraj S., Reddy P.M. (2014). Dry matter production, yield attributes, yield and quality of clusterbean [Cyamopsis tetragonoloba (L.) Taub.] as influenced by nitrogen and zinc application. Indian Journal of Agricultural Research. 48. 
Rajput A., Singh T. (1996). Response of nitrogen and phosphorus with and without Rhizobium inoculation on fodder production of cowpea (Vigna unguiculata). Indian Journal of Agronomy. 41: 91-94.

Rathke G.-W., Christen O., Diepenbrock W. (2005). Effects of nitrogen source and rate on productivity and quality of winter oilseed rape (Brassica napus L.) grown in different crop rotations. Field crops research. 94: 103-113.

Said-Al Ahl H. (2005). Physiological studies on growth, yield and volatile oil of dill (Anethum graveolens), Ph. D. Thesis, Fac. Agric. Cairo Uni. Egypt.

Saritha M., Vijayakumari B., Hiranmai Y., Kandari L. (2013). Influence of selected organic manures on the seed germination and seedling growth of cluster bean (Cyamopsis tetragonoloba (L.) Taub). Science, Technology and Arts Research Journal. 2: $16-21$.

Shu S., Guo S.-R., Yuan L.-Y. (2012). A review: polyamines and photosynthesis, Advances in Photosynthesis-Fundamental Aspects, InTech.

Singh A., Jat N., Singh R., Pal S., Singh A.K., Gudade B. (2014). Effect of fertility levels and bioinoculants on growth, productivity and economics of cluster bean (Cyamopsis tetragonoloba). Indian J. Agril. Sci. 84: 784-786.

Singh R., Singh R. (1989). Effect of nitrogen, phosphorus and seeding rates on yield, nutrient uptake and water use of guar under dryland conditions. Annals of Agricultural Research. 10: 299-306.

Tahir M.M., Abbasi M.K., Rahim N., Khaliq A., Kazmi M.H. (2009). Effect of Rhizobium inoculation and NP fertilization on growth, yield and nodulation of soybean (Glycine max L.) in the sub-humid hilly region of Rawalakot Azad Jammu and Kashmir, Pakistan. African Journal of Biotechnology. 8: 6191.

Verma M., Sharma S., Prasad R. (2011). Liquid Biofertilizers: Advantages over carrier-based biofertilizers for sustainable crop production. Newsl. Intern. Soc. Environ. Bot 17. 